\title{
Tannin-based extracts of Mimosa tenuiflora bark: features and prospecting as wood adhesives
}

\author{
Pedro Jorge Goes Lopes ${ }^{1,2}$, Leandro Calegari 1,3, Wagner Alex de Medeiros Silva³, Darci Alberto Gatto 2,5, \\ Pedro Nicó de Medeiros Neto ${ }^{3}$, Rafael Rodolfo de Melo ${ }^{4}$, Ivonete Alves Bakke ${ }^{1,3}$, Rafael de Avila Delucis ${ }^{5^{*}}$ (D) \\ and André Luiz Missio 5
}

\section{${ }^{*}$ Correspondence:}

r.delucis@hotmail.com

${ }^{5}$ Centro de Desenvolvimento

Tecnológico (CDTec),

Universidade Federal de

Pelotas, Pelotas, Rio Grande

do Sul state 96010-610, Brazil

Full list of author information

is available at the end of the

article

\begin{abstract}
Mimosa tenuiflora (Willd.) Poir. (MT) is an underutilized plant specie since its wood is mostly used for energy production. Nonetheless, the bark from this forest plant has a high amount of tannins and other valuable compounds. Tannins have high worldwide importance and, because of that, there is an increasing number of researches on biorefinery systems aiming at maximizing their exploitation. The present study evaluated tannins extracted from the MT bark and their use for producing wood adhesives. Three types of powdered tannins were extracted using different solvents: a pure aqueous solution, a $5 \%$ sodium hydroxide $(\mathrm{NaOH})$ aqueous solution, and a $5 \%$ sodium bisulfite $\left(\mathrm{NaHSO}_{3}\right)$ aqueous solution. Distilled water, wheat flour, and formaldehyde were also used as a solvent, a glue extender, and a catalyst, respectively. These adhesives were applied for bonding pine wood joints and their shear strengths were determined. All the MT-based adhesives showed high viscosities and, yielded glue lines with similar shear strengths and similar shear deformations if compared to each other. That tanninbased glue incorporated with the tannin extracted using $\mathrm{NaOH}$ or $\mathrm{NaHSO}_{3}$ stood out and yielded similar bonding performances if compared to a commercial adhesive applied as a positive control.
\end{abstract}

Keywords: Jurema-preta, Valuable raw material, Powder tannins, $\mathrm{NaOH}, \mathrm{NaHSO}_{3}$, Tannin adhesives

\section{Introduction}

Located at the semi-arid Brazilian region, the caatinga vegetation has a restricted timber production for several commercial purposes, such as furniture, lumbers, and civil engineering. Most of these available trees have high tortuosities and are overturned before developing high diameters. Therefore, sustainable management of non-timber forest products (NTFPs) emerges as an important complementary alternative for some communities, which depend on this biome to survive.

In the last decades, the concept of sustainability has gained prominence, especially after the Rio-92 Conference. This term can be briefly defined as the ability of humans 
to use available resources and meet their current needs, preserving the ability of future generations in also meeting their needs. According to the Brazilian Institute of Geography and Statistics-IBGE [1], NTFPs have been progressively exploited in Brazil and reached their highest production value in 2018. For instance, açai berry ( $\mathrm{R} \$ 592.0 \mathrm{mil}-$ lion), yerba mate ( $\mathrm{R}$ \$ 468.4 million), Brazil nuts ( $\mathrm{R}$ 130.9 million), carnauba wax ( $\mathrm{R}$ 189.2 million), and babassu almonds ( $\mathrm{R} \$ 92.1$ million) also reached outstanding production values in their respective markets [1].

Vegetable tannins (natural polyphenolic compounds) also stand out for their high market values $\left(0.7-1.5 € \mathrm{~kg}^{-1}\right)$ [2]. Among these resources, condensed tannins are responsible for the largest global production (about 90\%) with about 200 thousand tons per year $[3,4]$. For this reason, numerous forest species have been used as matrices for extracting tannins, including Acacia mearnsii, Acer sp., Quercus sp., Pinus spp., and Schinopsis spp. In this context, MT (commonly called as jurema-preta) is a native plant from the caatinga vegetation and its bark has a high amount of tannins [5, 6].

In general, vegetable tannins have high reactivity $[7,8]$, ability to combine proteins [9] and metals [10], as well as antifungal [11] and antioxidant [12] activities. These substances have a highly branched chemical structure $[2,13]$, which hinders their isolation, purification, and even their characterization. For this reason, they are usually sold as liquid or powdered extracts. Missio et al. [12] studied a powdered industrial tannin (IT) and reported that it is rich in condensed tannins (70-80\%) and also have a minor portion of non-tannic materials, such as hydrocolloid gums, sugars, and small molecules (20-30\%). Chemical modifications can be performed in condensed tannins through the incorporation of reactants, like hydrolysis and sulfonation reactions [2]. These reactions may increase the extraction yield and the overall quality of the tannin extract (including its solubility) to adjust these features of tannin-based extracts to each required use, like adhesives for wood products.

Currently, several bio-based adhesives have been developed to gradually replace synthetic ones designed for the timber industry. These ecological solutions may replace those conventional products with technical, environmental, and economic advantages. For instance, that lignin leftover from the pulp and paper industry is rich in phenolic hydroxyl groups, which increase its reactivity towards formaldehyde due to activation of the aromatic ring in o-position. This feature is commonly exploited for using lignin as a partial replacement of the phenols in phenol-formaldehyde adhesives [14]. Proteins obtained from the mechanical or solvent extraction of oils, soy, palm, canola, cottonseed and sunflower oils can also be promising sources of adhesives designed to bond wooden materials. Li and co-workers produced soy protein adhesives under highly alkaline conditions and reported high viscosity and low solids content [15]. Compared to a commercial phenol-formaldehyde resin, their bio-based adhesive reached superior shear strengths for bonding plywood designed for external applications [15].

Suitable bonding qualities were already attributed to these green compounds designed for glueing wood surfaces, although there are numerous physical and chemical influential factors related to pressing conditions, adhesive, wood, and their interfaces [14-16]. The use of condensed tannins (extracted from the MT bark) as raw materials to obtain novel products or by-products may follow some concepts, like bioeconomy and integrated biorefinery systems. This means that the valuable chemical compounds belonging 
to biomasses must be extracted based on profitable pathways and the involved environmental issues must be taken into account from an economic perspective.

Some recent studies intended to extract tannin compounds from certain forest species, which may encourage commercial plantations of these undervalued trees. These extracts were applied to produce adhesives for wood glues. For instance, Araujo et al. [17] investigated adhesives produced with tannins extract from bark Myrcia eximia, which is a native specie from the Amazon rainforest. According to them, their environmentally friendly adhesives for wood presented high quality, which was ascribed to the high condensed tannins content from the bark extracts. Ndiwe et al. [18] also obtained tough tannin-based adhesives produced by using extracts from two African tree barks (Vachellia nilotica and Senegalia Senegal). In this paper, tannin-based extracts were obtained from MT bark using different solvents and their potential to produce wood adhesives were ascertained. Additionally, an industrial tannin was used as a positive control.

\section{Material and methods}

\section{Raw materials}

The vegetal sample came from Fazenda Experimental do Núcleo de Pesquisas do Semiárido (NUPEÁRIDO), which belongs to Universidade Federal de Campina Grande (UFCG) and has the geographic coordinates of $07^{\circ} 05^{\prime} 10^{\prime \prime} \mathrm{S}$ and $37^{\circ} 15^{\prime} 43^{\prime \prime} \mathrm{W}$. A random sampling of ten (shrubs and trees) MT was performed during the summer and these individuals were overturned. Subsequently, their barks were removed, mixed, and airdried in the shade. Then, they were fragmented in a hammer mill (forage) coupled to a 150 mesh screen (opening of $1.00 \mathrm{~mm}$ ). The homogenized material was then hermetically sealed using nylon bags.

The IT (Phenotan $\mathrm{M}^{\circledR}$ ) consisted of a powder extract from Acacia mearnsii De Wild. bark and was donated by TANAC S/A, which is located at Montenegro, Brazil. Detailed information on the constitution and the performed industrial extraction was reported in previous manuscripts $[2,12,19]$. Pine wood samples were obtained from a local market located at Patos, Brazil. Sodium hydroxide $(\mathrm{NaOH})$ and sodium bisulfite $\left(\mathrm{NaHSO}_{3}\right)$, both of them in micro-pearls and analytical grade, as well as formaldehyde $\left(\mathrm{CH}_{2} \mathrm{O}, 37 \mathrm{wt} . \%\right.$ aqueous solution) and hydrochloric acid $(\mathrm{HCl}, 10 \mathrm{M}$ aqueous solution) were purchased from Neon Comercial (Suzano, Brazil). All these chemicals were used as supplied.

\section{Production of the tannin-based extracts}

For obtaining both tannin-based liquid (LE) and powdered (PTE) extracts, the moisture content (MC) of the bark (sample with $10 \mathrm{~g}$ ) was determined according to the ASTM D6403 [20]. Three solvents were used, distilled water $(5000 \mathrm{~mL}), 0.5 \% \mathrm{NaOH}$ aqueous solution, and $0.5 \% \mathrm{NaHSO}_{3}$ aqueous solution. The aqueous solvent and the MT bark (air-dried) sample were mixed at a 10:1 weight ratio in all extractions. The extraction process was carried out into a vertical autoclave (a stainless steel cylindrical reservoir) at a constant temperature of $120^{\circ} \mathrm{C}$ and a pressure of $0.09 \mathrm{MPa}$ for $150 \mathrm{~min}$. Four replicates (extractions) were performed for each solvent.

After the extractions, the LE was purified by sieving on a quantitative filter paper (grade 40:8 $\mu \mathrm{m}$ ) coupled to a Millipore system and a vacuum pump. The $\mathrm{pH}$ and 
temperature of the solutions and purified LE were determined (triplicates) along with both extraction and purification steps. Soon after the filtration step, the purified LE (each repetition) was immediately reduced to a dry powder in an oven with forced air circulation adjusted at $70 \pm 2{ }^{\circ} \mathrm{C}$ for $48 \mathrm{~h}$. The mass was registered for determining the crude PTE content (Eq. 1).

$$
\mathrm{EYc}=\left(\frac{\mathrm{Mc}}{\mathrm{Mp}}\right) \times 100
$$

where: EYc is the crude powder extract content (in \%), Mc is the dry mass of crude powder extract (in g), and Mp is the dry mass of raw material (in g).

The crude PTE was processed in a Wiley mill coupled to a 60 mesh screen $(<0.25 \mathrm{~mm})$. The refined extracts were packed in opaque plastic bottles and hermetically sealed. The refined PTE content was calculated according to Eq. 2.

$$
\mathrm{EYr}=\left(\frac{\mathrm{Mr}}{\mathrm{Mp}}\right) \times 100
$$

where: EYr is the refined powder extract content (in \%), Mr is the dry mass of refined powder extract (in g), and Mp is the dry mass of raw material (in g).

\section{Characterization of the powdered tannin-based extracts (PTE) and CT}

Attenuated total reflectance with Fourier transform infrared spectroscopy (ATR/FTIR) was used to analyse the refined PTE and CT. For that, a Nexus 470 (Thermo Nicolet brand) infrared spectrophotometer was adjusted to total absorbance. For each sample (1.0 mg), 32 scans were performed at the $4000-600 \mathrm{~cm}^{-1}$ spectral range with an applied resolution of $4.0 \mathrm{~cm}^{-1}$. The obtained spectra were normalized, and their baselines were corrected.

For preparing analytical solutions, $6.0 \mathrm{~g}$ of each tannin sample was gradually mixed with $1000 \mathrm{~mL}$ of distilled water at a constant temperature of $95{ }^{\circ} \mathrm{C}$. The material was then naturally cooled and stored according to the D3790, D4904, and D4905 standards [21-23]. Total solids content (TS) was determined according to D4902 and D4903 [24, $25]$. The MC was calculated by the difference between the total mass (100\%) and the TS. The MC influences the other parameters (soluble and insoluble solids, condensed tannins, and non-tannins) and, because of that, these chemical parameters of the PTE were adjusted to its MC using Eq. 3.

$$
\mathrm{M}_{0 \%}=\mathrm{Ms} \times\left[1-\left(\frac{\mathrm{MC}}{100}\right)\right]
$$

where: $\mathrm{M}_{0 \%}$ is the dry mass (in g), Ms is the air-dry mass (in g), and $\mathrm{MC}$ is the moisture content (in \%).

A $100 \mathrm{~mL}$ aliquot of the analytical solution was filtered in a quantitative filter paper (grade 40: $8 \mu \mathrm{m}$ with medium speed and retention). Thus, the soluble solids content (SS) was determined by the gravimetric method, based on the dry mass (filtrate liquid) measured after a drying process performed in an oven with forced air circulation $\left(100 \pm 4{ }^{\circ} \mathrm{C}\right)$. The insoluble solids content (IS) was the difference between the TS and the SS according 
to the NBR 14,362 and D6402 [26, 27]. Condensed tannins content (CT) was measured based on the reactivity of the extract (aliquot with $0.4 \%$ pure condensed tannins) with formaldehyde using Eq. 4, as reported in the literature [28-30]. For this, an amount of $100 \mathrm{~mL}$ of filtered aliquot was subjected to a Stiasny reaction by adding $2 \mathrm{~mL}$ of $\mathrm{HCl}$ and $8 \mathrm{~mL}$ of $\mathrm{CH}_{2} \mathrm{O}$. This mixture was kept under reflux for $30 \mathrm{~min}$ and stirring every $5 \mathrm{~min}$. The generated precipitate was filtered on quantitative filter paper (40: $8 \mu \mathrm{m}$ grade with medium speed and retention) and was then washed using distilled water and dried at $100 \pm 4{ }^{\circ} \mathrm{C}$ in an oven with forced air circulation adjusted. The non-tannins content (NT) was obtained by the difference between the SS and the CT (Eq. 5). The condensed tannins content in the aliquot of the analytical solution was determined using Eq. 6 . When any repetition did not meet a concentration of $0.4 \pm 0.025 \%$ (using $6.0 \mathrm{~g}$ ), an adequate amount of air-dried powder extract was used as a replacement (Eq. 7).

$$
\begin{aligned}
& \mathrm{CT}=\left(\frac{\mathrm{Mpt}}{\mathrm{M}_{0 \%}}\right) \times 100 \\
& \mathrm{NT}=\mathrm{SS}-\mathrm{CT} \\
& \mathrm{Ct}=\left[\frac{(\mathrm{Ma}+100)}{\mathrm{A}}\right] \\
& \mathrm{Me}_{\mathrm{c}}=\left[\frac{(\mathrm{Ma} \times 0.4)}{\mathrm{Ct}}\right]
\end{aligned}
$$

where: CT is the condensed tannins content (in \%), Mpt is the dry mass of the precipitate extrapolated to the total volume of the beneficiary's extract solution (in $\mathrm{g}$ ), $\mathrm{M}_{0 \%}$ is the dry mass of the powder extract used in the preparation of the analytical solution (in g), NT is the non-tannins content (in \%), SS is the soluble solids content (in \%), Ct is the concentration of pure condensed tannins in the aliquot (in \%), $\mathrm{Ma}_{\mathrm{t}}$ is the dry mass of the precipitated condensed tannins (in g), $\mathrm{A}$ is the aliquot volume (in $\mathrm{mL}$ ), $\mathrm{Me}_{\mathrm{c}}$ is the appropriate mass of the powder extract to a concentration (in g), and Ma is the air-dried mass of the powder extract used in the preparation of the analytical solution (in g).

\section{Characterization of the tannin-based adhesives}

Tannin-based adhesives were prepared using both the refined PTE and IT (Phenotan $\mathrm{M}^{\circledR}$ ) according to the formulations displayed in Table 1 . The experiment was carried out in triplicates for each adhesive formulation. All the adhesives were prepared as indicated by IT supplier, except the $\mathrm{MT}+\mathrm{NaOH}$ (refined PTE) since its concentration hinder adequate hydration of the extract. The powdered extract was mixed with distilled water at a constant $60^{\circ} \mathrm{C}$ and was then kept at room temperature for $24 \mathrm{~h}$ until reaching its equilibrium moisture content. Wheat flour and formaldehyde were applied as a glue extender and a catalyst, respectively. The flour had a particle size smaller than $0.25 \mathrm{~mm}$ (60 mesh).

The solid content (SC) of the tannin-based adhesives was determined by evaporation of the moisture in a $1.0 \mathrm{~g}$ sample oven-dried with forced air circulation adjusted at $100 \pm 4{ }^{\circ} \mathrm{C}$. The SC was calculated according to Eq. 8. Viscosity was determined using 
Table 1 Formulation of the different tannin-based adhesives

\begin{tabular}{lllll}
\hline Sample code & Base agent $^{\mathbf{a}} \mathbf{( g )}$ & Solvent $(\mathbf{g})$ & $\begin{array}{l}\text { Glue extender }^{\mathbf{b}} \\
(\mathbf{w} / \mathbf{w})\end{array}$ & $\begin{array}{l}\text { Formaldehyde }^{\mathbf{c}} \\
(\%)\end{array}$ \\
\hline $\mathrm{MT}$ & 50 & 50 & 10 & 20 \\
$\mathrm{MT}+\mathrm{NaOH}$ & 30 & 70 & 10 & 20 \\
$\mathrm{MT}+\mathrm{NaHSO}_{3}$ & 50 & 50 & 10 & 20 \\
$\mathrm{CT}$ & 50 & 50 & 10 & 20 \\
\hline
\end{tabular}

a Moisture content $\sim 6-8 \%$

b Based on the mass of the resin mix

c Percentage in relation to the mass of base agent (powdered tannin)

an EEQ-9031 analog rotational viscometer (Brookfield-LV type) [31], with a rotor spindle no. 3 and a rotation speed suitable to each adhesive. The $\mathrm{pH}$ at room temperature $\left(25 \pm 2{ }^{\circ} \mathrm{C}\right)$ was determined before and after the addition of $\mathrm{CH}_{2} \mathrm{O}$ using a LUCA-210 digital benchtop pH meter [32]. The gel time was measured based on that method reported by [33] after the incorporation of the $\mathrm{CH}_{2} \mathrm{O}$ (in a proportion of $20 \%$ of the mass of SC).

$$
\mathrm{SC}=\left(\frac{\mathrm{Md}}{\mathrm{Ma}}\right) \times 100
$$

where: SC is the solid content of adhesive (in \%), Md is the dry mass of adhesive sample (in g), and Ma is the mass of adhesive sample (in g).

\section{Bonding of the wood joints and their evaluation}

The selected pine wood boards presented basic density, apparent density, and moisture content of $0.37,0.43 \mathrm{~g} \mathrm{~cm}^{-3}$, and $9.53 \%$, respectively. This raw material was transformed into prismatic specimens with the dimensions of $1.90 \times 5.10 \times 5.40 \mathrm{~cm}^{3}$ (tangential $\times$ radial $\times$ longitudinal). To prepare the wood surfaces for bonding, they were sanded in the longitudinal direction using an electric circular sander (sandpaper no. 120). A weight of $300 \mathrm{~g} \mathrm{~m}^{-2}$ of each tannin-based adhesive was applied on the tangential plane and spread with a glass trowel, in a manner that only one tangential plane had the glue before the assembly. A manual assembly was then carried out for $15 \mathrm{~min}$, which was followed by a cold pre-pressing for $30 \mathrm{~min}$, and then a hot pressing at $120{ }^{\circ} \mathrm{C}$ and $0.5 \mathrm{MPa}$ for $60 \mathrm{~min}$. Finally, the samples were post-cured at room temperature for 15 days.

The glue line of the pine wood joints was analysed by scanning electron microscopy (SEM) using a Tescan (VEGA-3) equipment. The radial plane was coated with gold particles to ensure a suitable electrical conductivity, and the SEM images were acquired under an accelerating voltage of $10 \mathrm{kV}$. The glue line was evaluated for shear strength following the ASTM D905 [34]. For that, a compressive load was applied on the transverse plane (i.e. the load was parallel to the glued plane, which became a shear plane). All mechanical tests were carried out using a Shimadzu universal testing machine with a $100 \mathrm{kN}$ cell (Fig. 1a). Afterwards, the glued plane was visually evaluated and the percentage of failed wood was determined according to ASTM D5266 [35]. Based on the total shear plane, this indicates the percentage of cohesive failure in the wood. For that, it was used a transparent checkered grid with one hundred equal parts and the dimensions of 


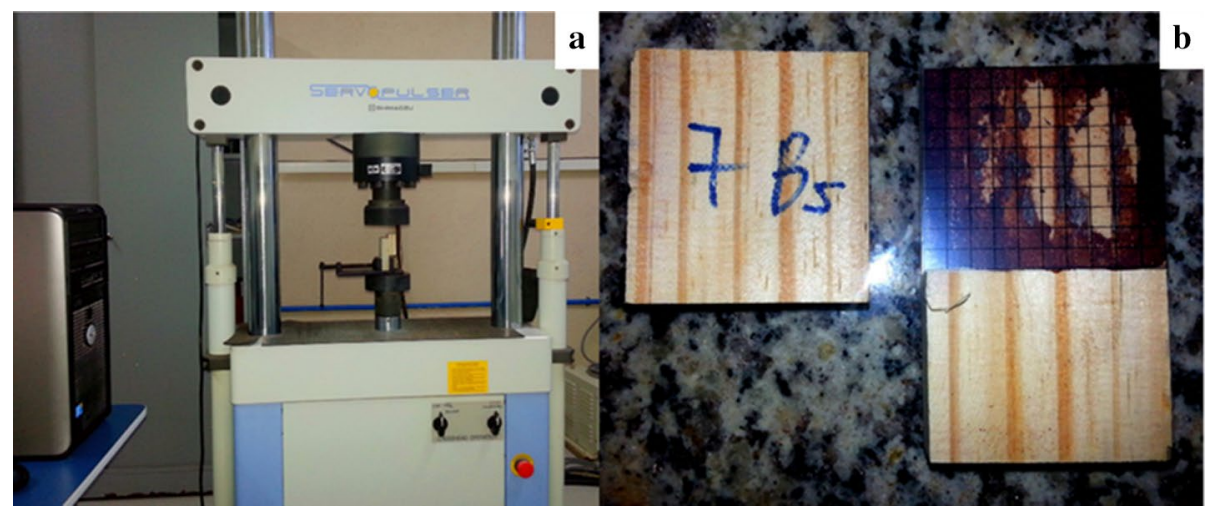

Fig. 1 Photographs of the shear test setup (a) and the glued plane of a failed pine wood sample (b)

Table 2 Temperature and $\mathrm{pH}$ of the different solutions of $\boldsymbol{M}$. tenuiflora bark

\begin{tabular}{|c|c|c|c|}
\hline Extraction condition & Solution sample & $\mathrm{pH}$ & Temperature $\left({ }^{\circ} \mathrm{C}\right)$ \\
\hline \multirow[t]{3}{*}{ MT } & Water & $6.30 \pm 0.37$ & $26.4 \pm 0.3$ \\
\hline & Bark Mixa & $4.76 \pm 0.19$ & $26.6 \pm 0.3$ \\
\hline & Purified LE & $4.21 \pm 0.16$ & $26.4 \pm 0.1$ \\
\hline \multirow[t]{3}{*}{$\mathrm{MT}+\mathrm{NaOH}$} & Water & $6.30 \pm 0.33$ & $26.9 \pm 0.1$ \\
\hline & Bark and $\mathrm{NaOH} \mathrm{Mix}^{\mathrm{a}}$ & $12.48 \pm 0.17$ & $26.6 \pm 0.4$ \\
\hline & Purified LE & $8.55 \pm 0.14$ & $26.0 \pm 0.6$ \\
\hline \multirow[t]{3}{*}{$\mathrm{MT}+\mathrm{NaHSO}_{3}$} & Water & $6.55 \pm 0.43$ & $27.0 \pm 0.6$ \\
\hline & Bark and $\mathrm{NaHSO}_{3} \mathrm{Mix}^{\mathrm{a}}$ & $4.66 \pm 0.15$ & $27.0 \pm 0.7$ \\
\hline & Purified LE & $4.87 \pm 0.06$ & $27.7 \pm 2.5$ \\
\hline
\end{tabular}

${ }^{a}$ After $15 \mathrm{~min}$. Where numerals refer to averages \pm standard deviations.

$4.40 \times 5.10 \mathrm{~cm}^{2}$ (length $\times$ width) (Fig. 1b). Also, the MC of the samples was determined by gravimetric analyses soon after the mechanical tests.

\section{Statistical analyses}

Data normality and homoscedasticity of variances were verified using Shapiro-Wilk tests and Bartlett tests, respectively. A completely randomized design was applied. The data were subjected to analysis of variance (ANOVA) followed by Fisher-Snedecor tests. When the null hypothesis was rejected, a comparison of means was performed using Fisher tests. A significance level of $5 \%$ was adjusted for all tests.

\section{Results and discussion}

\section{Evaluation of the extraction process}

The water (used in all treatments) presented a slightly acidic $\mathrm{pH}$, as shown in Table 2. The addition of the MT bark induced strong acidification in the aqueous solution due to the leaching of some organic extractives, like condensed tannins (for instance, proanthocyanidins, and saponins), sugars (c.a. glucose, starch, terpenoids, and alkaloids) [36-39], and minerals (a minor amount). This occurs due to the high polarity of the water (used as a solvent), which causes progressive solubilisation of some hydrophilic compounds from the MT bark. Among the extractives belonging to tree barks, some water-soluble 


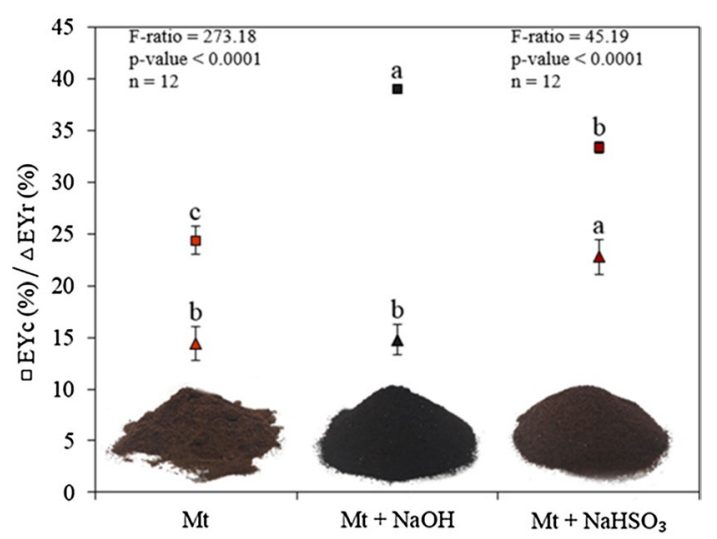

Fig. 2 Crude (EYc) and refined (EYr) PTE contents and side view of them. Averages ( \pm standard deviations) followed by a same letter, in a same column, do not differ statistically from each other according to the Fisher test

tannins (polyphenolic molecules) and weak acids release $\mathrm{H}^{+}$ions in the aqueous solution, leading to the deprotonation of hydroxyls. Similar results were obtained with the addition of bark and $\mathrm{NaHSO}_{3}$, which induced a slight increase in the $\mathrm{pH}$ of the purified LE. The low $\mathrm{pH}$ of the sulphated LE can be attributed to the acid character of $\mathrm{NaHSO}_{3}$. which induced a slight increase in the $\mathrm{pH}$ of the purified LE. The low $\mathrm{pH}$ of the sulphated LE can be attributed to the acid character of NaHSO3, which generally ranges from 4.0 to 5.0 [40].

The incorporation of bark and $\mathrm{NaOH}$ led to increases in the $\mathrm{pH}$ of the solution (normally strongly alkaline) due to the dissociation of hydroxyl ions $\left(\mathrm{OH}^{-}\right)$. The solution generated strong odour gases when heated and the purified LE demonstrated a decrease in $\mathrm{pH}$ after the extraction process. The $\mathrm{NaOH}$ is a strong base prone to solubilizes in an aqueous medium through an exothermic chemical process [40], which promotes the attack of free radicals present in the vegetable raw material (c.a. bark) and leads to the removal and conversion of soluble substances belonging to the extract.

\section{Powder extract yields}

The air-dried particles of the MT bark showed MC and dry mass of $11.25 \pm 0.44 \%$ and $443.79 \mathrm{~g}$, respectively. Besides, there were no significant differences between groups. The yields of PTE was the first parameter to determine the extractive content belonging to the bark, which indicates the efficiency and productivity of the extractions. Regarding the crude powder extract content (EYc), the addition of $\mathrm{NaOH}$ or $\mathrm{NaHSO}_{3}$ favoured a significant increase in the removal of extractives from the raw material. However, the former extracting agent promoted a higher percentage of extracted solids. Regarding the refined powder extract content (EYr), only the treatment with the addition of the latter extracting agent, significantly favoured the conversion into powder during beneficiation, as shown in Fig. 2.

Based on these yields, the additions of the extracting agents (through hydrolysis and sulfitation) promoted significant increases in the extraction of solid tannin fractions from the MT bark. Some previous studies also found similar results using other 
extracting agents $[2,13,40]$. In the present study, the EYc values can be mainly attributed to the use of basic hydrolysis $(\mathrm{NaOH})$ and sulfitation $\left(\mathrm{NaHSO}_{3}\right)$.

Regarding the composition of the extracts from the MT bark, several phenolic (like tannins) and non-phenolic substances (such as carbohydrates, esters, and insoluble inorganic compounds) were detected [6]. According to the literature [13], high purity tannins can be extracted using high levels of pressure and temperature, which leads to greater solubility of compounds, as well as decreased viscosity and improved movement of the solvents. However, an over-oxidation of the phenolic compounds may occur if the extraction takes a long time, which negatively affects the final extraction yield and its quality.

Regarding the $\mathrm{MT}+\mathrm{NaOH}$, there was a little transformation of the crude extract and, thus, significant loss (about 24\%) during its processing, which was mainly due to the extraction and formation of more rigid components. This indicates that this solid phase is not easily fragmented into particle sizes less than 60 mesh $(0.250 \mathrm{~mm})$. In addition, the grinding of the crude powder extract probably affected the EYr due to a large amount of solid material being superimposed on the internal sieve of the rotation drum, consequently impairing the passage to the collection reservoir. This probably hindered the contact between the rotating rods from the mill and the particles from the powder.

\section{Analysis of powdered tannin-based extracts (PTE)}

FTIR spectra indicate the chemical structure of the different PTE and IT (Fig. 3). According to Tondi [41], the $1800-600 \mathrm{~cm}^{-1}$ range is the most important region for tannins. In general, if compared to each other, the powder extracts have a similar molecular chemical structure since these differences are only related to the intensities of the existing bands, as well as minor displacements in some bands located at the $1630-650 \mathrm{~cm}^{-1}$ range. Briefly, the bands at 1800-1650,1650-1400, 1400-1100, and 1100-600 $\mathrm{cm}^{-1}$

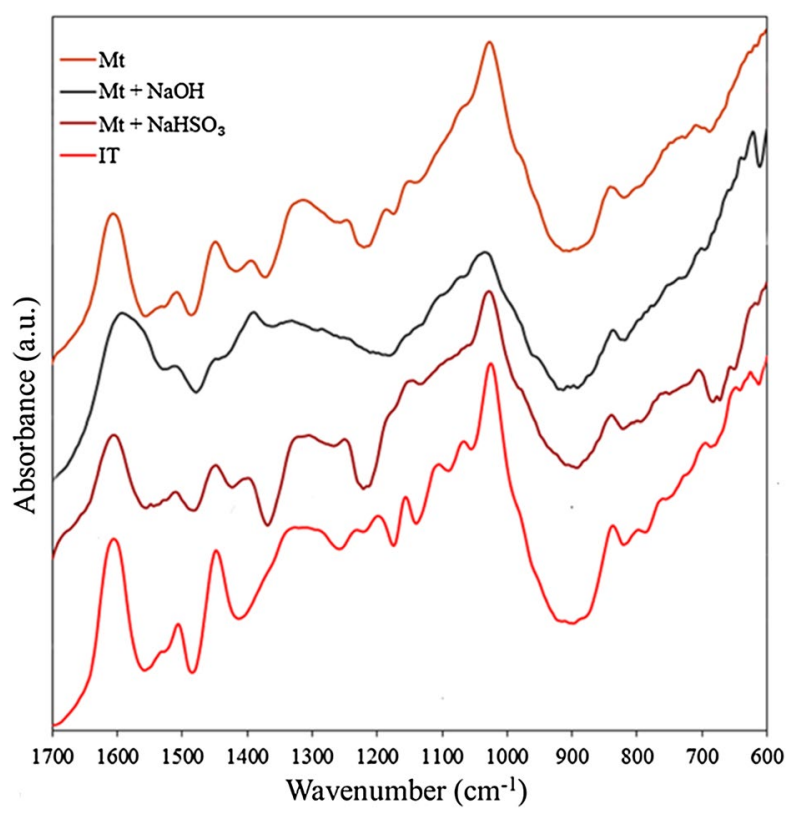

Fig. 3 FTIR spectra of the powdered tannin-based extracts 
refers to $\mathrm{C}-\mathrm{O}$ stretching, $\mathrm{C}=\mathrm{C}$ stretching in aromatic rings from phenolic compounds, $\mathrm{C}-\mathrm{O}$ elongation in aromatic phenolics, and $\mathrm{C}-\mathrm{H}$ elongation in aromatic compounds, respectively [41]. These bands also indicate the presence of certain building blocks from proanthocyanidins, such as profisetidin, procyanidin, prorobinetinidin, and prodelphinidin, which present similar reactivity to that of phenol from formaldehyde [41].

In comparisons between the tannin-based extracts, the $\mathrm{MT}+\mathrm{NaOH}$ showed the highest TS and the lowest MC (Table 3). The higher MC presented by the IT may be due to its higher hygroscopicity ascribed to its smaller particle size $(<100$ mesh, $0.15 \mathrm{~mm})$ when compared to the other tannins $(<60$ mesh). This smaller particle diameter may lead to a greater surface area and, consequently, this tannin probably became prone to form chemical bonds with the humidity from the environment. These features also lead to a lower amount of solid powder extract. The inclusion of extracting agents in the extraction process provided significant increases in the overall solubility of the PTE extracted from the MT bark. These results are comparable to those obtained for the CT. The use of the extracting agent $\left(\mathrm{NaOH}\right.$ and $\left.\mathrm{NaHSO}_{3}\right)$ also yielded an increase in SS from PTE and a decrease in the IS extracted from the MT bark.

In this study, only the properties obtained for the $\mathrm{MT}+\mathrm{NaOH}$ PTE meet the parameters proposed by the IS6199-1971 [42]. This standard procedure regards a powdered black wattle extract and indicates that MC, IS, and tannic SS shall be of at least of 6.77, 1.22 , and $67.29 \%$, respectively. Compared to the unmodified MT, the $\mathrm{MT}+\mathrm{NaOH}$ showed a significant increase in $\mathrm{CT}$ and a decrease in NT, which yielded improvements in the PTE extracted under neat water. The use of $\mathrm{MT}+\mathrm{NaHSO}_{3}$ also resulted in greater CT if compared to the unmodified MT, although the NT remained similar in this case. These results are different from those reported in a previous study on MT bark and some extractions done under hot water [43]. These divergences can be explained by some differences in extracting procedures, as well as differences in the used raw materials (like particle size of and extraction mechanism).

For the PTE, high values of both SS and CT are desired. In this sense, the use of $\mathrm{MT}+\mathrm{NaOH}$ and $\mathrm{MT}+\mathrm{NaHSO}_{3}$ yielded higher values of these parameters. Low values of IS and NT are surely desired. However, with sulfitation, the same behaviour occurred for the CT and without the influence reducing of NT compounds. It

Table 3 Characterization of the powdered tannin-based extracts (PTE) and Phenotan $\mathbf{M}^{\circledR}$ (IT)

\begin{tabular}{lllllll}
\hline Powder (Sample) & TS & MC & SS & IS & CT & NT \\
& (\%) & & & & & \\
\hline MT $(8.30 \mathrm{~g})$ & $91.62 \mathrm{~b} \pm 1.24$ & $8.38 \mathrm{~b} \pm 1.24$ & $87.27 \pm 2.28$ & $12.78 \pm 2.18$ & $53.88 \mathrm{~d} \pm 1.39$ & $33.38 \pm 1.98$ \\
$\mathrm{MT}+\mathrm{NaOH}(6.50 \mathrm{~g})$ & $93.19 \mathrm{a} \pm 0.78$ & $6.81 \mathrm{c} \pm 0.78$ & $98.78 \pm 0.58$ & $1.40 \pm 0.48$ & $68.31 \mathrm{~b} \pm 1.68$ & $31.29 \pm 0.99$ \\
$\mathrm{MT}+\mathrm{NaHSO}(7.10 \mathrm{~g})$ & $92.01 \mathrm{ab} \pm 1.51$ & $7.98 \mathrm{bc} \pm 1.51$ & $97.16 \pm 1.36$ & $2.84 \pm 1.36$ & $63.49 \mathrm{c} \pm 1.84$ & $34.79 \pm 1.88$ \\
IT (6.00 g) & $88.45 \mathrm{c} \pm 1.47$ & $11.55 \mathrm{a} \pm 1.47$ & $96.55 \pm 1.58$ & $3.63 \pm 1.07$ & $77.73 \mathrm{a} \pm 0.65$ & $20.05 \pm 0.73$ \\
F-ratio & 17.21 & 17.21 & - & - & 282.28 & - \\
p-value & $<0.0001$ & $<0.0001$ & - & - & $<0.0001$ & - \\
$\mathrm{n}$ & 34 & 34 & 30 & 31 & 29 & 32 \\
\hline
\end{tabular}

Where: According to the Fisher-Snedecor test, averages ( \pm standard deviations) followed by the same letter, in the same column, do not differ statistically from each

TS total solids, MC moisture content, SS soluble solids, IS insoluble solids, CT condensed tannin, NT non-tannins 
is well known that sulfitation promotes the opening of heterocyclic rings of tannins and introduce sulfonic groups, which also lead to a reduction in the viscosity and increases in both extraction yield and solubilisation of tannins [2, 28]. The alkaline hydrolysis process promotes rearrangement of the tannins through the rupture of the interflavonoid bond (C4-C8) and the opening of the heterocyclic ring connected to the ring of the flavonoid unit, which induce an increase in the solubility of the tannins, especially CT [2].

\section{Properties of the tannin-based adhesives}

The $\mathrm{SC}$ of the $\mathrm{MT}+\mathrm{NaOH}$-based adhesive was lower than the others (Table 4). This adhesive was formulated with a lower concentration of the base agent in the PTE and a greater amount of solvent (distilled water), which explains the lowest SC and the highest viscosity attributed to this adhesive. In this study, the modification at the time of hydration and solubilization of the PTE was performed to avoid reactivations of the solid compounds. When carried out in very alkaline conditions (like in the present study), the extraction of tannins produces high viscosity adhesives, which can hinder their subsequent use [44]. The reduction in viscosity is a common characteristic of the sulfitation of the LE and PTE, as it favours the breakdown of chemical bonds from the extract and, thus, leads to an increase in the viscosity of the adhesives. In addition, this may promote increases in both $\mathrm{pH}$ and gel time, which explains these results shown in Table 4.

Adhesives with viscosity mean greater than $1500 \mathrm{cP}$ cannot be applied via microparticles and those above $6000 \mathrm{cP}$ are not suitable to be applied on solid woods [45]. However, they can be applied directly and manually on the wood using spatulas or rollers. The higher viscosity of adhesives can yield the formation of a glue line thicker than that ideal due to an uneven distribution on the wood surface and inadequate wetting of the adhesive [16].

The $\mathrm{pH}$ of the adhesives must not exceed the 2.5-11.0 range [46], although the $\mathrm{pH}$ of the wood is also important since it affects that time required for total curing and hardening of the glue. There were decreases in the $\mathrm{pH}$ of all the adhesives due to the addition of the catalyst $\left(\mathrm{CH}_{2} \mathrm{O}\right)$. After mixing, chemical reactions started in the adhesive solution (with the release of $\mathrm{H}^{+}$ions), which ended above $90{ }^{\circ} \mathrm{C}$ and caused a

Table 4 Averages and standard deviations for the solid contents, viscosity, and potential hydrogens with $(\mathrm{pHc})$ and without $(\mathrm{pHnc})$ catalyst and gel time for the tannin-based adhesives

\begin{tabular}{llclll}
\hline Adhesive (sample) & $\mathbf{S C}(\%)$ & Viscosity (cP) & $\mathbf{p H}_{\mathbf{n c}}$ & $\mathbf{p H}_{\mathbf{c}}$ & Gel time (s) \\
\hline MT & $53.47 \pm 0.68$ & $5233 \pm 57$ & $4.21 \pm 0.04$ & $4.01 \pm 0.02$ & $75 \pm 2.65$ \\
$\mathrm{MT}+\mathrm{NaOH}$ & $28.57 \pm 0.36$ & $10,333 \pm 305$ & $7.63 \pm 0.03$ & $7.34 \pm 0.03$ & $88 \pm 2.65$ \\
$\mathrm{MT}+\mathrm{NaHSO}_{3}$ & $53.49 \pm 1.24$ & $4233 \pm 57$ & $5.25 \pm 0.02$ & $4.84 \pm 0.01$ & $101 \pm 4.36$ \\
IT & $52.22 \pm 0.73$ & $2013 \pm 128$ & $4.82 \pm 0.03$ & $4.62 \pm 0.02$ & $126 \pm 6.56$ \\
\hline
\end{tabular}

where: numerals refer to averages \pm standard deviations

SC solids content, $p H n c$ hydrogen potential without using the catalyst agent, $p H c$ hydrogen potential using the catalyst agent 
phase change to form the adhesive gel (by a complete cure of the resin). The extracting agents significantly increased the gel time (phase change), which is desired since adhesives with a very short gel time hinder an adequate spreading over the wood surface since a rapid polymerization may occur, leading to decreases in the glue line strength.

The condensation of tannins due to the presence of formaldehyde under heating $\left(95-100{ }^{\circ} \mathrm{C}\right)$ is strongly influenced by the $\mathrm{pH}$ of the medium, as there is an increase in the reaction speed if there is a decrease in the $\mathrm{pH}$ [47]. According to Tondi, an amount of about $4 \%$ of this catalyst is enough to promote the polymerization of tannin-based resins [40]. These results are similar to those reported by Azevêdo et al. [45], who produced sulfited $\left(\mathrm{Na}_{2} \mathrm{SO}_{3}\right)$ tannin adhesives extracted from the MT bark cut in the dry period (August-December). They obtained the following parameters: $\mathrm{pH}$ values from 5.69 to 5.76 , SC from 46.8 to $46.9 \%$ and viscosity from 2067 to 10,000 cP, which are similar to the present study. Some minor differences in a comparison with the present study are probably associated with the acid sulfitation process after extracting the bark, which was not done in the present study. The IT resin (Phenotan $\mathrm{M}^{\circledR}$ ) extracted from the black wattle bark is commercialized with an MC of 5-8\%, a viscosity (at $25^{\circ} \mathrm{C}$ ) from 1000 to $1600 \mathrm{cP}$, and a pH ranging from 4.0 to 5.0 [17]. The IT adhesive showed the lowest viscosity among those analysed here, as well as the greatest fluidity and, consequently, this adhesive was easily spread on the wood surface.

\section{Bonding performance of the tannin-based adhesives}

The different tannin-based adhesives used for bonding the wood joints promoted uniform glue lines as shown in Fig. 4, in which the glue lines are highlighted by red arrows. All the MT adhesives promoted thick glue lines in the union between the wood surfaces, mainly due to their high viscosity. In general, this may impair the

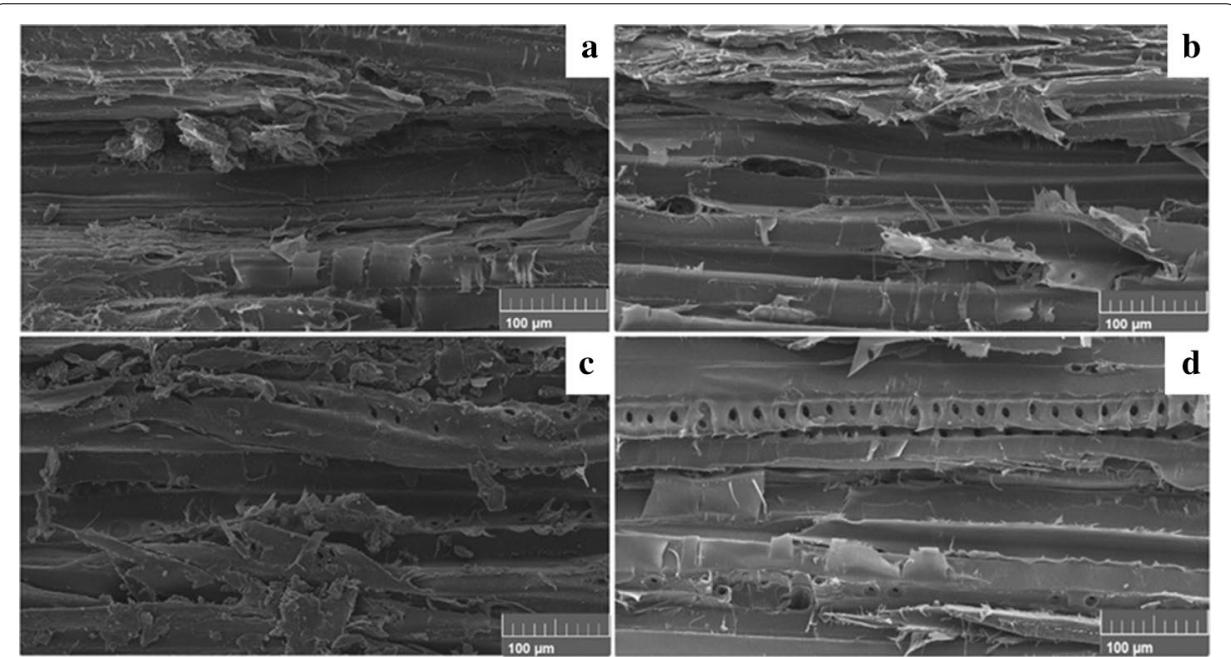

Fig. 4 Side view of the glue lines promoted by the bonding with the tannin-based adhesives. Where $a, b, c$, and d refer to $\mathrm{MT}, \mathrm{MT}+\mathrm{NaOH}, \mathrm{MT}+\mathrm{NaHSO}_{3}$, and Phenotan $\mathrm{M}^{\circledR}(\mathrm{IT})$, respectively 
Table 5 Physical-mechanical properties of the wood joints glued with different tanninbased adhesives

\begin{tabular}{llll}
\hline Adhesive sample & MC (\%) & Shear strength (MPa) & Wood failure (\%) \\
\hline MT & $7.03 \pm 0.29$ & $1.41 \mathrm{a} \pm 0.54$ & $41.09 \mathrm{a} \pm 7.26$ \\
$\mathrm{MT}+\mathrm{NaOH}$ & $7.26 \pm 0.23$ & $1.51 \mathrm{a} \pm 0.73$ & $44.13 \mathrm{a} \pm 3.44$ \\
$\mathrm{MT}+\mathrm{NaHSO}_{3}$ & $7.43 \pm 0.21$ & $1.27 \mathrm{ab} \pm 0.53$ & $40.70 \mathrm{a} \pm 4.55$ \\
IT & $7.35 \pm 0.23$ & $0.76 \mathrm{~b} \pm 0.37$ & $35.11 \mathrm{~b} \pm 6.03$ \\
F-ratio & - & 3.36 & 5.36 \\
p-value & - & 0.0269 & 0.0033 \\
n & 48 & 48 & 45 \\
\hline
\end{tabular}

Where: MC is moisture content of the glued wood sample (dry basis). According to the Fisher-Snedecor test, averages ( \pm standard deviations) followed by the same letter, in the same column, do not differ statistically from each.

adhesive-wood connection but may positively contribute to the union in the internal layers of the adhesive. This fact may limit its full capacity of undergoing external loads on a large scale, such as shear forces.

The shear strengths of the MT and MT $+\mathrm{NaOH}$ adhesives overcame that of the IT (Table 5). The same behaviour was demonstrated in the evaluation of the percentage of wood failure on the shear plane. According to a previous study [48], the bonding of wood joints with tannin-based adhesives often do not reach a minimum safety rate due to the low viscosity of the tannin resins and, consequently, high leakage lines are normally formed. These results are contrasting with those of the present study, which is probably due to the viscosity of the adhesives and their chemical composition.

According to the NBR 7190 [49], the shear strength parallel to the fibres in softwoods varies from 4 to $6 \mathrm{MPa}$ for a $0.4-0.5 \mathrm{~g} \mathrm{~cm}^{-3}$ basic density range. Moreover, according to the ASTM D5751 [50], the shear strength mean for glued joints must reach at least $60 \%$ of shear strength belonging to the respective solid wood. Based on these different standards, those shear strengths displayed in Table 4 should range between 2.4 and 3.6 MPa. The ASTM D2559 [51] also indicates that, for a satisfactory bonding with structural adhesives (designed for outdoor uses), a minimum average value of $75 \%$ of wood failure must be reached. The minimum percentage of failed wood is $60 \%$ for dried laminated joints and other non-structural joints, which is visualized on the shear plane [42]. In this evaluation, the higher the percentage of wood failure, the higher the bonding quality, which is mainly associated with characteristics of both adhesive-adhesive and adhesive-wood interfaces. None of the adhesives reached these levels established by ASTM D2259. This may be related to the high viscosity of the different adhesives from MT bark. This factor probably impaired the spreading and wetting of the glue on the wood surfaces, thus, negatively affecting the cohesion between adhesive molecules and the overall adhesive-wood interface. Moreover, to use a more efficient glue spreader would be beneficial. Although the IT resin is commonly used for the manufacture of plywood and other structural wood parts [17], in this study, its use was adapted for lateral bonding of wood joints, which probably impaired its mechanical performance.

The phenomenon of connections at the adhesive-wood and adhesive-adhesive interfaces depends on several simultaneous factors, such as anatomy, physics and chemistry of the wood, physicochemical properties of the adhesive, and the bonding process. A decrease in the viscosity of the adhesive may favour an improvement of the bonding quality. This 
would provide an improved penetration into the wood and thus increase in both the shear strength of the glue line and the percentage of wood failure on the shear plane.

\section{Conclusions}

Some valuable compounds from the $M$. tenuiflora bark have been wasted since this forest specie is traditionally underutilized. In the present study, an integrated and sustainable processing was applied to produce wood adhesives with properties comparable to a commercial product. Aqueous solutions containing $0.5 \%$ of $\mathrm{NaOH}$ or $0.5 \%$ of $\mathrm{NaHSO}_{3}$ were successfully used as solvents to extract tannin-based compounds. Tannin-based adhesives were then produced and yielded glued wood joints with promising mechanical performances, although these parameters did not meet known standard procedures. Nevertheless, the novel tannin-based adhesives showed better performances if compared to a commercial structural adhesive (IT). Further studies are strongly encouraged and may address different pressing conditions, the influence of the adhesive viscosity and even the use of a mechanised system for the adhesive spreading.

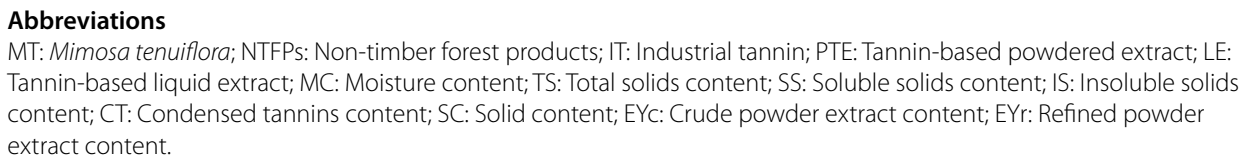

Acknowledgements

The authors wish to thank Taninos da Acácia S.A. (TANAC $\left.{ }^{\circledR}\right)$ for the donation of the industrial tannin extract, as well as Dr. John Kennedy Guedes Rodrigues and Mr. Eduardo Tenório (Laboratório de Engenharia de Pavimentos/UFCG) for the mechanical tests. Also, we would like to acknowledge the English revision of Miss Bia Carneiro.

The authors would like to thank CNPq and CAPES for supporting this work.

\section{Authors' contributions}

PJGL, WAMS, PNMN, and RRM developed the experiments and analysed the results. PJGL, LC, RAD, and ALM proposed experimental solutions, validated the initial objectives of the project, and wrote the original draft. LC, IAB, and DAG were responsible for the funding acquisition. RAD helped for reviewing, editing and correcting both spelling and grammar errors. All authors read and approved the final manuscript.

\section{Funding}

No funding has been provided for the research associated with this article.

\section{Availability of data and materials}

All relevant data is presented in the manuscript, and additional information can be made available on request if necessary.

\section{Competing interests}

The authors declare that they have no known competing financial interests or personal relationships that could have appeared to influence the work reported in this paper.

\section{Author details}

${ }^{1}$ Programa de Pós-Graduação Em Ciências Florestais (PPGCF), Universidade Federal de Campina Grande, Patos, Paraíba state 58708-110, Brazil. ${ }^{2}$ Programa de Pós-Graduação Em Engenharia Florestal (PPGEF), Universidade Federal de Santa Maria, Santa Maria, Rio Grande do Sul state 97105-900, Brazil. ${ }^{3}$ Unidade Acadêmica de Engenharia Florestal (UAEF), Universidade Federal de Campina Grande, Patos, Paraíba state 58708-110, Brazil. ${ }^{4}$ Departamento de Ciências Agronômicas E Florestais (DCAF), Universidade Federal Rural Do Semi-Árido, Mossoró, Rio Grande do Norte state 59625-900, Brazil. ${ }^{5}$ Centro de Desenvolvimento Tecnológico (CDTec), Universidade Federal de Pelotas, Pelotas, Rio Grande do Sul state 96010-610, Brazil.

Received: 17 November 2020 Accepted: 16 January 2021

Published online: 26 January 2021

\section{References}

1. Brazilian Institute of Geography and Statistics. Produção da extração vegetal e da silvicultura (PEVS). 2019. https:// sidra.ibge.gov.br/pesquisa/pevs/quadros/brasil/2018. Accessed 02 March 2020. 
2. Arbenz A, Avérous L. Chemical modification of tannins to elaborate aromatic biobased macromolecular architectures. Green Chem. 2015. https://doi.org/10.1039/C5GC00282F.

3. Pizzi A. Recent development in eco-efficient bio-based adhesives for wood bonding: opportunities and issues. $J$ Adhes Sci Technol. 2006. https://doi.org/10.1163/156856106777638635.

4. Pizzi A. Natural adhesives, binders, and matrices for wood and fiber composites: chemistry and technology. In: Aguilera A, Davim JP, editors. Research developments in wood engineering and technology. PA/USA: IGI Global, Hershey; 2014. p. 131-81.

5. Lopes PJG, Calegari L, Calegari CCA, Oliveira E, Stangerlin DM, Gatto DA. Produtividade em casca e taninos condensados de jurema-preta. Nativa. 2015. https://doi.org/10.14583/2318-7670.v03n02a04.

6. Calegari L, Lopes PJG, Oliveira E, Gatto DA, Stangerlin DM. Quantificação de taninos nas cascas de jurema-preta e acácia-negra. Pesq Flor Bras. 2016. https://doi.org/10.4336/2016.pfb.36.85.986.

7. Sánchez-Martín J, González-Velasco M, Beltrán-Heredia J. Acacia mearnsii de wild tannin-based flocculant in surface water treatment. J Wood Chem Technol. 2009. https://doi.org/10.1080/02773810902796146.

8. Pizzi A. Tannins: prospectives and actual industrial applications. Biomolecules. 2019. https://doi.org/10.3390/biom9 080344.

9. Adamczyk B, Simon J, Kitunen V, Adamczyk S, Smolander A. Tannins and their complex interaction with different organic nitrogen compounds and enzymes: old paradigms versus recent advances. ChemistryOpen. 2017. https:// doi.org/10.1002/open.201700113.

10. Tondi G, Oo CW, Pizzi A, Trosa A, Thenevon MF. Metal adsorption of tannin-based rigid foams. Ind Crops Prod. 2009. https://doi.org/10.1016/j.indcrop.2008.06.006.

11. Ogawa S, Yazaki Y. Tannins from Acacia mearnsii De Wild. bark: tannin determination and biological activities. Molecules. 2018. https://doi.org/10.3390/molecules23040837.

12. Missio AL, Tischer B, Santos PSB, Coldevilla C, Menezes CR, Barin JS, Haselein CR, Labidi J, Gatto DA, Petutschnigg A, Tondi G. Analytical characterization of purified mimosa (Acacia mearnsii) industrial tannin extract: single and sequential fractionation. Sep PurifTechnol. 2017. https://doi.org/10.1016/j.seppur.2017.06.010.

13. Shirmohammadli Y, Efhamisisi D, Pizzi A. Tannins as a sustainable raw material for green chemistry: a review. Ind Crops Prod. 2018. https://doi.org/10.1016/j.indcrop.2018.10.034.

14. Zhang W, Ma Y, Wang C, Li S, Zhang M, Chu F. Preparation and properties of lignin-phenol-formaldehyde resins based on different biorefinery residues of agricultural biomass. Ind Crop Prod. 2013. https://doi.org/10.1016/j.indcr op.2012.07.037.

15. Li K, Peshkova S, Gen X. Investigation of soy protein-kymene ${ }^{\circledR}$ adhesive systems for wood composites. J Am Oil Chem Soc. 2004. https://doi.org/10.1007/s11746-004-0928-1.

16. Hemmilä V, Adamopoulos S, Karlsson O, Kumar A. Development of sustainable bio-adhesives for engineered wood panels—a review. RSC Adv. 2017. https://doi.org/10.1039/C7RA06598A.

17. Araujo ES, Lorenço MS, Zidanes UL, Sousa TB, Mota GS, Reis VNO, da Silva MG, Mori FB. Quantification of the bark Myrcia eximia DC tannins from the Amazon rainforest and its application in the formulation of natural adhesives for wood. J Clea Prod. 2021. https://doi.org/10.1016/j.jclepro.2020.124324.

18. Ndiwe B, Pizzi A, Tibi B, Danwe R, Konai N, Amirou S. African tree bark exudate extracts as biohardeners of fully biosourced thermoset tannin adhesives for wood panels. Ind Crop Prod. 2019. https://doi.org/10.1016/j.indcr op.2019.02.023.

19. Taninos da Acácia SA, Phenotan M. 2020. http://www.tanac.com.br/sites/default/files/CT_PHENOTAN_M_EN_0.pdf. Accessed 24 August 2020

20. American Society for Testing and Materials International. D6403-99: standard test method for determining moisture in raw and spent materials. West Conshohocken, PA/USA. 2014.

21. American Society for Testing and Materials International. D4904-99: standard practice for cooling of analytical solutions. West Conshohocken, PA/USA. 2016.

22. American Society for Testing and Materials International. D4905-99: standard practice for preparation of solution of solid, pasty and powdered vegetable tannins extracts. West Conshohocken, PA/USA. 2016.

23. American Society for Testing and Materials International. D3790-17: standard test method for volatile matter (moisture) of leather by oven drying. West Conshohocken, PA/USA. 2017.

24. American Society for Testing and Materials International. D4902-99: standard test method for evaporation and drying of analytical solutions. West Conshohocken, PA/USA. 2016.

25. American Society for Testing and Materials International. D4903-99: standard test method for total solids and water in vegetable tanning material extracts. West Conshohocken, PA/USA. 2016.

26. Associação Brasileira de Normas Técnicas. NBR 14362: insumos: tanantes: determinação do teor de sólidos solúveis e insolúveis: método por gravidade. Rio de Janeiro, RJ/Brazil. 2008.

27. American Society for Testing and Materials International. D6402-99: standard test method for determining soluble solids and insoluble in extracts of vegetable tanning materials. West Conshohocken, PA/USA. 2014.

28. Ping L, Pizzi A, Guo ZD, Brosse N. Condensed tannins extraction from grape pomace: characterization and utilization as wood adhesives for wood particleboard. Ind Crops Prod. 2011. https://doi.org/10.1016/j.indcrop.2011.02.009.

29. Chupin L, Motillon C, Charrier-El Bouhtoury F, Pizzi A, Charrier B. Characterization of maritime pine (Pinus pinaster) bark tannins extracted under different conditions by spectroscopic methods, FTIR and HPLC. Ind Crops Prod. 2013. https://doi.org/10.1016/j.indcrop.2013.06.045.

30. Saad H, Khoukh A, Ayed N, Charrier B, Charrier-El Bouhtoury F. Characterization of Tunisian Aleppo pine tannins for a potential use in wood adhesive formulation. Ind Crops Prod. 2014. https://doi.org/10.1016/j.indcrop.2014.07.035.

31. Associação Brasileira de Normas Técnicas. NBR 9277: adesivos: determinação da viscosidade: método do viscosímetro Brookfield. Rio de Janeiro, RJ/Brazil. 2014.

32. Associação Brasileira de Normas Técnicas. NBR 11119: insumos: tanante: determinação do pH. Rio de Janeiro, RJ/ Brazil. 2008.

33. Santiago SB, Gonçalves FG, Lelis RCC, Segundinho PGA, Paes JB, Arantes MDC. Colagem de madeira de eucalipto com adesivos naturais. Rev Mater. 2018. https://doi.org/10.1590/s1517-707620180003.0485. 
34. American Society for Testing and Materials International. D905-08: standard test method for strength properties of adhesives bonds in shear by compression loading. West Conshohocken, PA/USA. 2013.

35. American Society for Testing and Materials International. D5266-13: standard practice for estimating the percentage of wood failure in adhesive bonded joints. West Conshohocken, PA/USA. 2013.

36. Rivera-Arce E, Chávez-Soto MA, Herrera-Arellano A, Arzate S, Agüero J, Feria-Romero IA, Cruz-Guzmán A, Lozoya X. Therapeutic effectiveness of a Mimosa tenuiflora cortex extract in venous leg ulceration treatment. J Ethnopharmacol. 2007. https://doi.org/10.1016/j.jep.2006.08.032.

37. Souza RSO, Albuquerque UP, Monteiro JM, Amorim ELC. Jurema-Preta (Mimosa tenuiflora [Willd.] Poir.): a review of its traditional use, phytochemistry and pharmacology. Braz Arch Biol Technol. 2008. https://doi.org/10.1590/S1516 $-89132008000500010$.

38. La Torre A, Caradonia F, Gianferro M, Molinu MG, Battaglia V. Activity of natural products against some phytopathogenic fungi. Commun Agric Appl Biol Sci. 2014;79(3):439-49.

39. Rangel-Vazquéz NA, Félix FR. Chapter 5: Mimosa Tenuiflora. In: Rangel-Vazquéz NA, Félix FR, editors. Computational chemistry applied in the analyses of Chitosan/Polyvinylpyrrolidone/Mimosa Tenuiflora. New York, NY: Science Publishing Group; 2014. p. 67-81.

40. Santiago SB, Gonçalves FG, Paes FB, Lelis RCC, Vidaurre GB, Arantes MD. Condensed tannins extracted from eucalyptus bark waste. Floresta. 2019. https://doi.org/10.5380/rf.v49i1.56141.

41. Tondi G. Tannin-based copolymer resins: synthesis and characterization by solid state ${ }^{13} \mathrm{C}$ NMR and FT-IR spectroscopy. Polymers. 2017. https://doi.org/10.3390/polym9060223.

42. Bureal of Indian Standards. IS 6199-1971: specification for Wattle extract. New Delhi, India. 2006.

43. Medeiros JX, Calegari L, Silva G, Oliveira E, Pimenta A. Measurement of tannic substances in forest species. Floram. 2018. https://doi.org/10.1590/2179-8087.058916.

44. Panamgama LA. Polyphenolic extracts of Pinus radiata bark and networking mechanisms of additive-accelerated polycondensates. J Appl Polym Sci. 2007. https://doi.org/10.1002/app.24466.

45. Azevêdo TKB, Paes JB, Calegari L, Nascimento JWB. Qualidade dos taninos de jurema-preta (Mimosa tenuiflora) para a produção de adesivo tanino formaldeído. Ci Fl. 2014. https://doi.org/10.5902/1980509818470.

46. Bianche JJ, Texeira APM, Ladeira JPS, Carneiro ACO, Castro RVO, Della Lucia RM. Cisalhamento na linha de cola de Eucalyptus sp. colado com diferentes adesivos e diferentes gramaturas. Floram. 2017.

47. Vieira MC, Lelis RCC, Rodrigues ND. Propriedades químicas de extratos tânicos da casca de Pinus oocarpa e avaliação de seu emprego como adesivo. Cerne. 2014. https://doi.org/10.1590/S0104-77602014000100006.

48. Gonçalves FG, Segundinho PGA, Schayder LF, Tinti VP, Santiago SB. Avaliação da resistência ao cisalhamento da madeira de Pinus sp. coladas em temperatura ambiente. Ci Mad. 2016. https://doi.org/10.12953/2177-6830/rcm. v7n1p42-50.

49. Associação Brasileira de Normas Técnicas. NBR 7190: projeto de estruturas de madeira. Rio de Janeiro, RJ/Brazil. 1997.

50. American Society for Testing and Materials International. D5751-99: standard specification for adhesives used for laminate joints in nonstructural lumber products. West Conshohocken, PA/USA. 2019.

51. American Society for Testing and Materials International. D2559-12a: standard specification for bonded structural wood products for use under exterior exposure conditions. West Conshohocken, PA/USA. 2018.

\section{Publisher's Note}

Springer Nature remains neutral with regard to jurisdictional claims in published maps and institutional affiliations.

\section{Submit your manuscript to a SpringerOpen ${ }^{\circ}$ journal and benefit from:}

- Convenient online submission

- Rigorous peer review

- Open access: articles freely available online

- High visibility within the field

- Retaining the copyright to your article

Submit your next manuscript at $\boldsymbol{\nabla}$ springeropen.com 